\title{
DISKUSI ONLINE : MANAJEMEN REFERENSI (APLIKASI MENDELEY) DALAM PENULISAN KARYA ILMIAH
}

\author{
Eka Astuty ${ }^{1}$, Elpira Asmin ${ }^{2}$, \& Eka Sukmawaty ${ }^{3}$ \\ ${ }^{1,2}$ Fakultas Kedokteran, Universitas Pattimura \\ ${ }^{3}$ Fakultas Sains dan Teknologi, UIN Alauddin Makassar \\ Email:eka.astuty@fk.unpatti.ac.id,eka.sukmawaty@gmail.com,elpira.asmin@fk.unpatti.ac.id
}

\begin{abstract}
One of the requirements for students to achieve a bachelor's degree is to write scientific papers. Bibliography and citations are important elements in writing scientific papers. The arrangement of these two things is done manually or by application. Mendeley is a commonly used citation software. This activity was carried out online using the zoom application because during the Covid-19 pandemic, direct socialization or outreach activities could not be carried out because of the suggestion of Physical distancing. During the presentation of the material, discussion participants were invited to ask questions. The discussion participants were very enthusiastic and there were many questions submitted, including reference sources that could be used in writing scientific papers and the types of writing styles found in the Mendeley application. Community service activities in the form of online discussions about reference management (Mendeley Application) in writing scientific papers are expected to provide knowledge and information specifically for participants who are final year students. This online discussion is expected to also become a forum to refresh knowledge about reference management for participants who are lecturers.
\end{abstract}

Keywords: Discussion, Online, Refference Management, Mendeley

ABSTRAK : Salah satu syarat yang harus dipenuhi oleh mahasiswa untuk mencapai gelar sarjana yaitu harus menulis karya tulis ilmiah berupa skripsi. Daftar pustaka dan sitasi menjadi elemen penting dalam penulisan karya ilmiah. Penyusunan dua hal tersebut dapat dilakukan secara manual ataupun dengan bantuan aplikasi. Mendeley merupakan salah satu perangkat lunak sitasi yang cukup mudah penggunaannya bagi orang awam sehingga menjadi favorit penulis. Kegiatan ini dilakukan secara daring memakai aplikasi zoom sebab di masa pandemi Covid- 19, kegiatan sosialisasi ataupun penyuluhan secara langsung tidak bisa dilakukan karena adanya anjuran Physical distancing. Selama berlangsungnya pemaparan materi, peserta diskusi dipersilahkan untuk mengemukakan pertanyaan. Peserta diskusi sangat antusias dan ada banyak pertanyaan yang disampaikan, diantaranya adalah sumber referensi yang bisa digunakan dalam penulisan karya ilmiah dan jenis-jenis gaya penulisan yang terdapat dalam aplikasi mendeley. Kegiatan pengabdian masyarakat dalam bentuk diskusi online tentang manajemen referensi (Aplikasi Mendeley) dalam penulisan karya ilmiah diharapkan dapat memberikan pengetahuan dan informasi terkhusus bagi peserta yang merupakan mahasiswa tingkat akhir. Diskusi online ini diharapkan juga menjadi wadah untuk me-refresh pengetahuan tentang manajemen referensi bagi peserta yang berprofesi sebagai dosen.

Kata Kunci: Diskusi, Daring, Manajemen Referensi, Mendeley

\section{PENDAHULUAN}

Karya ilmiah adalah hal yang tidak

asing bagi mahasiswa. Sejak baru menyandang status mahasiswa saja, mereka sudah dihadapkan dengan berbagai tugas seperti observasi, menganalisis, mengkritisi, dan lainnya yang pada akhirnya adalah pembuatan karya ilmiah sebagai laporan (Kurniadi, 2017).

Salah satu syarat yang harus dipenuhi oleh mahasiswa untuk mencapai gelar sarjana yaitu harus menulis karya tulis ilmiah berupa 


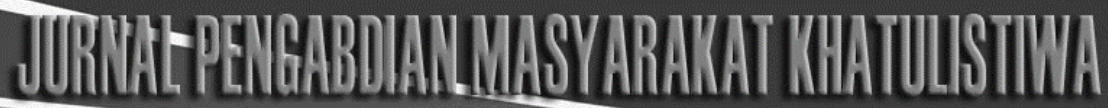

http://umalstkippersada.acid/jumal/index:php/JPMK

skripsi. Kewajiban publikasi ilmiah bagi mahasiswa S1, S2 dan S3 bahkan telah ditetapkan berdasarkan Surat Dirjen Dikti No. 152/E/T/2012 dan Surat Edaran Kemenristek DIKTI No. B/323/B.B1/SE/2019. Kini bukan hanya dosen yang berkewajiban berkarya dan menunjukkan bukti pelaksanaan Tri Dharma perguruan tinggi, tapis juga mahasiswa. Namun kewajiban ini menjadi tugas berat oleh mahasiswa karena kurangnya kemampuan dan kebiasaan dalam menyusun karya ilmiah (Abdul \& Muhammad, 2018).

(Wardani, Luh, Sri, \& Ginantra, 2020) menjelaskan bahwa salah satu keterampilan dalam menulis karya ilmiah adalah membuat daftar pustaka dan sitasi. Daftar pustaka dan sitasi menjadi elemen penting dalam penulisan karya ilmiah. Penyusunan dua hal tersebut dapat dilakukan secara manual ataupun dengan bantuan aplikasi. Mendeley merupakan salah satu perangkat lunak sitasi yang cukup mudah penggunaannya bagi orang awam sehingga menjadi favorit penulis. Kemudahan penggunaan aplikasi ini menjadi pertimbangan saat mengajarkan sitasi yang baik dan benar menggunakan software kepada mahasiswa yang baru pertama kali mengenal aturan sitasi beserta perangkat lunaknya (Yusdita \& Utomo, 2019).

(Fitriana \& Dewi, 2017) lebih lanjut menjelaskan bahwa sering terjadi penyalahgunaan dalam menggunakan informasi sebagai bahan referensi di kalangan mahasiswa, misalnya tidak mencantumkan sumber referensi baik pada sitasi maupun pada daftar referensi yang dapat mengakibatkan tindak plagiasi. Hal ini disebabkan karena kurangnya pengetahuan dan kesadaran mengenai berbagai aturan dan kebijakan dalam penggunaan sumber informasi sehingga mahasiswa perlu mengetahui reference management software yang dapat membantu dalam mengorganisir referensi serta penulisan sitasi dan daftar referensi secara otomatis

\section{METODE PELAKSANAAN}

Kegiatan pengabdian kepada masyarakat yang dilakukan secara daring ini merupakan hasil kerja sama dengan Program Studi Biologi, Fakultas Sains Teknologi UIN Alauddin Makassar dengan sasaran mahasiswa tingkat akhir.

Adapun tahapan yang dilakukan pada pelaksanaan kegiatan pengabdian ini sebagai berikut :

\section{Tahap Persiapan}

Koordinasi antara pemateri serta panitia pelaksana dalam pembuatan materi yang hendak di informasikan dan mempersiapkan flyer, setting aplikasi zoom, serta sertifikat kegiatan.

\section{Tahap Pelaksanaan}

Kegiatan ini dilakukan secara daring memakai aplikasi zoom sebab di masa pandemi Covid- 19, kegiatan sosialisasi ataupun penyuluhan secara langsung tidak bisa dilakukan karena adanya anjuran Physical distancing

Materi yang disampaikan dalam kegiatan diskusi online ini adalah :

1) Materi tentang sitasi 
2) Materi tentang manajemen referensi aplikasi Mendeley (Instalasi, Fitur-fitur Mendeley, Pemberian contoh penerapan Mendeley)

\section{HASIL DAN PEMBAHASAN}

Reference Manager / manajemen referensi berfungsi sebagai alat bantu pencarian, penyimpanan, dan penulisan dalam membuat karya tulis ilmiah. Dengan adanya media pengelola referensi ini dapat menampilkan fakta, data yang akurat, valid dan relevan (Nurhidayah, 2017), sehingga penulis termasuk mahasiswa dapat mempertanggung jawabkan karya ilmiahnya (hasil penelitian) pada masyarakat dan para pemakai informasi penelitian lainnya.

Ada berbagai macam jenis pengelola referensi yang banyak digunakan diseluruh dunia yaitu, EndNote, Zotero, Mendeley, NoodleTools, RefWorks, 4 Citavi, JabRef, Referencer, CiteULike, Docear, Qiqqa, BibSonomy, Colwiz, Connotea, BiblioScape, WizFolio, SciRef, KBibTex, BibBase, RefBase, Wikindx, Pybliographer, RefDB, Reference Manager, Sente, Aigaion, Bookends, Bebop, Bibus (Prasad, 2016)

Namun dalam kegiatan diskusi online ini, pemateri berfokus pada salah satu aplikasi manajemen referensi saja yaitu Mendeley karena metode pengoperasiannya lebih mudah sehingga cocok untuk digunakan untuk semua kalangan. Mendeley juga menyediakan penyimpanan online sebesar 2 GB untuk penggunanya secara gratis.

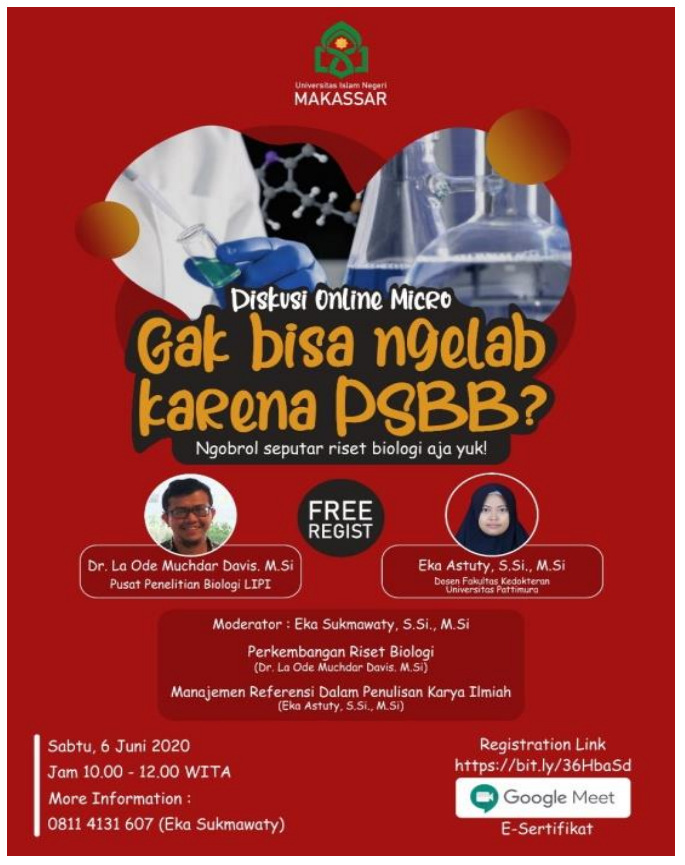

\section{Gambar 1. Flyer Kegiatan Diskusi Online}

Selain itu, berdasarkan penelusuran pada google trend, dari tahun 2004 sampai dengan saat ini, penggunaan manajer referensi dengan aplikasi mendeley oleh para peneliti dan akademisi berada pada peringkat pertama

Diskusi online yang dimulai dengan pemaparan materi pertama, pemateri menjelaskan terlebih dahulu apa yang dimaksud dengan sitasi dan kaitannya dengan kode etik penulisan karya ilmiah. Kode etik karya tulis ilmiah merupakan aturan yang perlu diperhatikan dalam penulisan karya ilmiah yang berkaitan dengan pengutipan dan perujukan terhadap data informasi yang digunakan, dan penyebutan sumber data (Dede, 2020).

Seorang penulis sebaiknya harus memiliki file dari referensi yang dijadikan acuan atau yang dikutip dan harus pernah dibaca dan diparafrase ke dalam tulisan dengan bahasa 


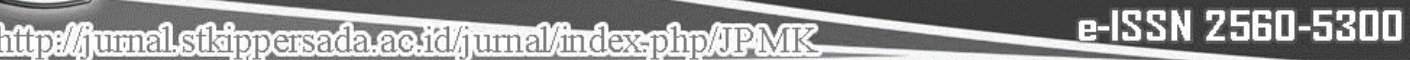

kita sendiri sehingga dapat dipertanggungjawabkan ketikan akan dikutip.

Pemaparan materi kemudian dilanjutkan dengan materi kedua yaitu tentang manajemen referensi aplikasi yaitu Mendeley. Pemateri menjelaskan langkah-langkah instalasi mendeley, cara memperbaiki metadata dari referensi, cara sitasi di Microsoft word dan membuat daftar pustaka secara otomatis.

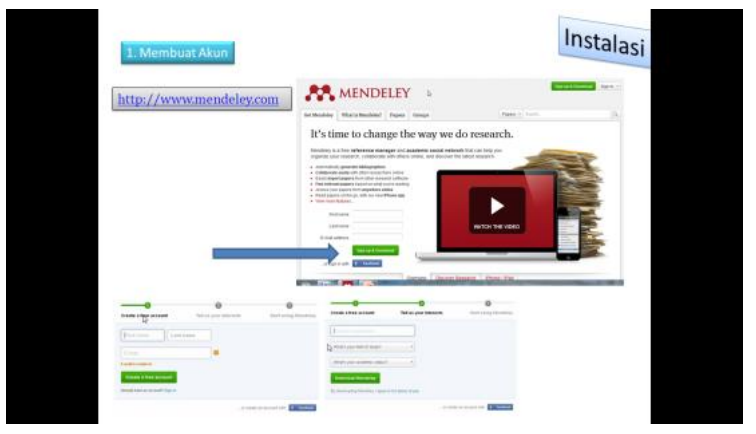

Gambar 2. Tangkapan layar (screen shoot) penjelasan instalasi aplikasi Mendeley

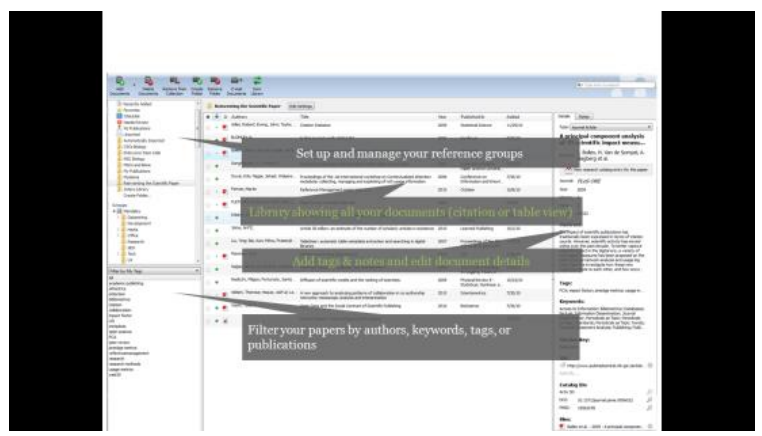

Gambar 3. Tangkapan layar (screen shoot) penjelasan fitur-fitur aplikasi Mendeley

Selama berlangsungnya pemaparan materi, peserta diskusi dipersilahkan untuk mengemukakan pertanyaan. Peserta diskusi sangat antusias dan ada banyak pertanyaan yang disampaikan, diantaranya adalah sumber referensi yang bisa digunakan dalam penulisan karya ilmiah dan jenis-jenis gaya penulisan yang terdapat dalam aplikasi mendeley.

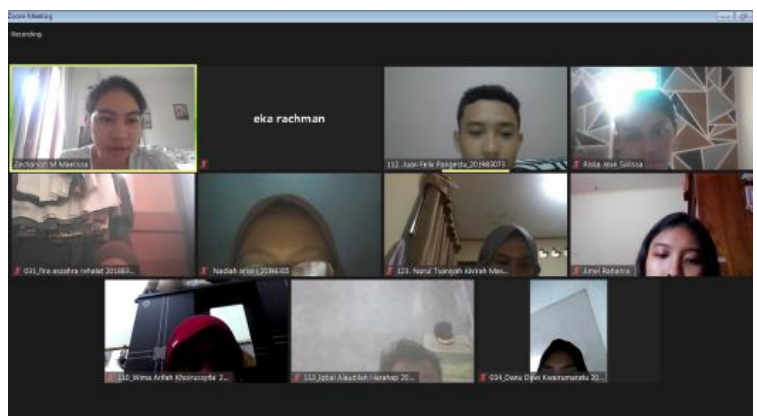

Gambar 4. Tangkapan layar (screen shoot) kegiatan diskusi online

Dalam penulisan karya ilmiah, dibutuhkan referensi yang tidak sedikit, sehingga penulis sering dihadapkan dengan masalah harus menelusuri kalimat yang dikutip satu per satu dan hal itu tentu sangat sulit jika harus mencari dan membaca file satu persatu hingga menemukan kalimat yang kita kutip. Masalah ini dapat dengan mudah ditangani dengan penggunaan aplikasi mendeley.

\section{SIMPULAN}

Kegiatan pengabdian masyarakat dalam bentuk diskusi online tentang manajemen referensi (Aplikasi Mendeley) dalam penulisan karya ilmiah diharapkan dapat memberikan pengetahuan dan informasi terkhusus bagi peserta yang merupakan mahasiswa tingkat akhir. Diskusi online ini diharapkan juga menjadi wadah untuk me-refresh pengetahuan tentang manajemen referensi bagi peserta yang berprofesi sebagai dosen. Sebagai saran, diharapkan kedepannya akan ada kegiatan serupa dengan durasi waktu yang lebih lama sehingga tidak hanya pemaparan materi dan diskusi tapi juga kegiatan praktik langsung. 


\section{DAFTAR RUJUKAN}

Abdul, S., \& Muhammad, I. B. (2018). KARYA TULIS ILMIAH BAGI MAHASISWA STKIP ANDI MATAPPA KABUPATEN PANGKEP. Jurnal Terapan Abdimas, 3(1), 39-43.

Dede, A. R. (2020). PENGELOAAN REFERENSI DAN SITASI DENGAN SOFTWARE MENDELEY. FAKULTAS EKONOMI DAN BISNIS, UNIVERSITAS SILIWANGI.

Fitriana, H. A., \& Dewi, A. O. P. (2017). Pengaruh Pengajaran Mendeley Reference Management Software Terhadap Ketepatan Penulisan Sitasi Dan Daftar Referensi (Studi Eksperimental Mahasiswa Prodi S-1 Ilmu Perpustakaan Angkatan 2014 Universitas Diponegoro). Jurnal Ilmu Perpustakaan, 6(4), 241250. Retrieved from https://ejournal3.undip.ac.id/index.php/ji p/article/view/23230

Kurniadi, F. (2017). Penulisan Karya Tulis Ilmiah Mahasiswa Dengan Media Aplikasi Pengolah Kata. AKSIS: Jurnal Pendidikan Bahasa Dan Sastra Indonesia, 1(2), 267-277. https://doi.org/10.21009/aksis.010208

Prasad, M. R. M. (2016). Usage of References and Its Management in Research. In Scholarly Communication and the Publish or Perish Pressures of Academia (pp. 118-142). https://doi.org/10.4018/978-1-52251697-2.ch007

Wardani, N. W., Luh, N., Sri, W., \& Ginantra, R. (2020). Pelatihan Aplikasi Mendeley untuk Referensi dalam Menulis Karya Ilmiah Bagi Guru SMK Dwijendra Denpasar. JURPIKAT (Jurnal Pengabdian Kepada Masyarakat), 1(1), 13-20.

Yusdita, E. E., \& Utomo, S. W. (2019). Pelatihan Pemanfaatan Mendeley Sebagai Reference Tool Pada Artikel Ilmiah Mahasiswa Pendidikan Akuntansi Unipma. Jurnal ABDINUS: Jurnal Pengabdian Nusantara, 3(1), 36. 